\title{
A Contribution to the Problem of Tree Necrosis in Cities: Soil Properties in the Habitat of Ulmus glabra Huds. and Ulmus minor Mill. Greenery Elements of the City of Kielce
}

\author{
Przyczynek do problemu zamierania drzew w miastach: \\ właściwości gleb w otoczeniu wiązu górskiego Ulmus glabra \\ Huds. i wiązu polnego Ulmus minor Mill. - składników zieleni Kielc
}

\begin{abstract}
- Dr hab. Anna Świercz, prof. nadzw., mgr Ewelina Zajecka - Faculty of Mathematics and Natural Science, Jan Kochanowski University in Kielce. Świętokrzyska 15 St., 25-406 Kielce, e-mail: swierczag@poczta.onet.pl, ewelina.smorzewska@gmail.com
\end{abstract}

Keywords: urban soils, tree necrosis in cities, soil salinity, soil contamination, elms

Słowa kluczowe: gleby miejskie, obumieranie drzew w miastach, zasolenie gleb, zanieczyszczenie gleb, wiązy

\begin{abstract}
Physicochemical properties of soils have a significant impact on the growth and development of vegetation. In urban areas, because of increased human activity, changes occur in both grainsize composition as well as physical and chemical properties of soils. These soils are frequently saline and contaminated with heavy metals, which limit the development of vegetation and cause its necrosis. Elm is a commonly growing tree with low habitat requirements, whose population has been considerably reduced because of progressing Dutch elm disease. This study attempts to assess the relationship of dependency between physicochemical parameters of soils and health status of elms from the area of the City of Kielce. Two elms were selected for the study, that is, one alive tree being a natural monument and one necrotic tree. The soil analysis concerned physicochemical parameters such as size composition, reaction, salinity measured by means of proper electrolyte conductivity (PEC), acidity, organic carbon content, carbonates, nitrogen, and selected elements including heavy metals $(\mathrm{Cu}, \mathrm{Pb}, \mathrm{Zn}, \mathrm{Cd}, \mathrm{Mn})$. The study indicates differentiation amongst the physicochemical parameters of the analysed soils. A characteristic feature of the soils being the habitat of the necrotic elm is that they have considerably higher salinity than those being the habitat of the alive elm. Increased levels of sodium and chlorides could negatively affect water transportation in vegetation what might have resulted, amongst others, in necrosis of the tree.
\end{abstract}

๑) IOŚ-PIB

\section{INTRODUCTION}

Urban phanerophytes are exposed to many stress-inducing factors aggravating their condition and, in extreme cases, causing their necrosis. Apart from major air pollutants, such as particulate matter, oxides of sulphur, nitrogen, carbon and fluorine, hydrocarbons and their derivatives, as well as tar substances [Szczepanowska 2001], alkaline dust immission and contamination of urban soils with salt and chlorine compounds become a serious problem [Baczewska et al. 2014, Cunningham et al. 2008,

\section{Streszczenie}

Właściwości fizyko-chemiczne gleb mają istotny wpływ na wzrost i rozwój roślinności. Na terenach miejskich z uwagi na nasiloną działalność człowieka zachodzą zmiany zarówno w składzie granulometrycznym, jak i właściwościach fizycznych i chemicznych gleb. Często gleby te są zanieczyszczone metalami ciężkimi i zasolone, co ogranicza rozwój roślinności i powoduje jej obumieranie. Wiąz jest pospolicie występującym drzewem o niskich wymaganiach siedliskowych, którego populacja została istotnie zredukowana z powodu postępującej holenderskiej choroby wiązów. W pracy podjęto próbę oceny zależności parametrów fizyko-chemicznych gleby od stanu zdrowotnego wiązów z terenu Kielc. Do badań wytypowano wiązy: drzewo żywe, objęte ochroną pomnikową oraz drzewo obumarłe. W glebie analizie poddano zawartość wybranych metali ciężkich $(\mathrm{Cu}, \mathrm{Pb}, \mathrm{Zn}, \mathrm{Cd}, \mathrm{Mn})$ oraz parametry fizykochemiczne, tj. odczyn, zasolenie mierzone przewodnością elektrolityczną właściwą PEW, kwasowość, zawartość węgla organicznego, węglanów, azotu oraz wybranych pierwiastków. Badania wskazują na zróżnicowanie parametrów fizykochemicznych w badanych glebach. Charakterystyczną cechą gleb będących siedliskiem wiązu obumarłego jest istotnie wyższe zasolenie w odniesieniu do siedliska wiązu żywego. Podwyższone zawartości sodu i chlorków mogły wpłynąć negatywnie na transport wody w roślinie, co mogło przyczynić się między innymi do obumarcia drzewa.
Czerniawska-Kusza et al. 2003, Gałuszka et al. 2010]. Excessive use of $\mathrm{NaCl}$ for combating snow and ice on roads and pavements translates into high concentrations of chloride and sodium ions, increase in $\mathrm{pH}$ of soil, as well as saturation of sorption complex with sodium [Dmuchowski, Badurek 2004, Hartl, Erhart 2002, Mazur et al. 2011]. These result in an increase in the osmotic pressure, which becomes inaccessible to tree roots, which in turn leads to physiological drought [Szczepanowska 2001]. Moreover, salt 
included in slush ice may mechanically damage shoots and buds, as mentioned by Borowski and Latocha in their article [2006]. The highest concentrations of salt in urban soils are recorded in their surface layers in the immediate vicinity of main roads. Chudecka [2013] indicated in her article that salt accumulates mainly in the green belt at the edge of a road. The content of salt in these soils may exceed the normal concentration of soil solutions even several times [Szczepanowska 2001]. Salinity of soils near roads reaches the highest concentration in the period from winter to spring [Gałuszka et al. 2010, Mazur et al. 2011]. Many factors, acting synergistically, enhance their detrimental effect during summer, when salt moves with atmospheric precipitations into deeper layers of a soil profile. During the periods of drought, in turn, an increase in salinity of upper soil layers is observed because of soaking in saline soil solutions [Breś 2008]. It is estimated that $\mathrm{NaCl}$ causes necrosis of up to $90 \%$ of trees in cities. A comprehensive analysis of soil properties may be a contribution to a broader discussion on necrosis of trees in urban areas. The direct aim of this study was to thoroughly analyse the physicochemical properties of soils and the habitats of field and wych elms: alive and necrotic trees (standing deadwood) as well as to indicate the soil factors that could have had an impact on the health status of the analysed urban trees.

\section{MATERIALS AND METHODS}

Two specimens of elm from the area of Kielce were selected for the study. Kielce is the provincial capital with nearly 2,100 inhabitants and compact urban development, where urban soils with transformed structure constitutes a large proportion. Comprehensive studies conducted in the area of Kielce indicate a natural content of heavy metals adopting maximum values in urban areas and in the vicinity of the main streets of the City [Świercz, Smorzewska 2015].

Detailed pedological studies were conducted in the vicinity of a necrotic tree, that is, field elm (Ulmus minor Mill) located on a private property at Batalianów Chłopskich Street and an alive tree, that is, wych elm (Ulmus glabra Hudsz) located on a private property at Prosta Street in Kielce. The necrotic elm at Batalionów Chłopskich Street has a circumference of $1.58 \mathrm{~m}$ at breast height and numerous root sprouts. The habitat of this elm comprises leached black soil [Polish Society of Soil Science 2009] developed of medium silt loam ( $\mathrm{msl}$ ) and belonging to class IIIb with a formation Aa-Apg-Ggg-CGor. The alive elm at Prosta Street has a circumference of $2.06 \mathrm{~m}$ at breast height, is about 90 years old and remains under monumental protection. The habitat of this elm comprises horticultural humus soils with a level of hortic AKho [Marcinek, Komisarek 2011]. The mixed soil samples from a distance of 0.5-1 m from a trunk of each tree were taken for the analysis. The samples were collected from two depths, that is, $0-0.2 \mathrm{~m}$ (organic-mineral sample) and $0.5-0.7 \mathrm{~m}$ (mineral sample) in Sptember 2013.

The following procedures were performed in all air-dry soil samples with three repetitions:

1. determination of $\mathrm{pH}$ with a potentiometric method;

2. determination of salinity (PEC);

3. determination of hydrolytic acidity Hh with Kappen's method;
4. determination of plant-available $\mathrm{P}_{2} \mathrm{O}_{5}$ with a spectrophotometric method in the extract of calcium lactate;

5. determination of plant-available $\mathrm{K}$ with a flame photometric method in the extract of calcium lactate;

6. determination of plant-available $\mathrm{Mg}$ with a flame atomic absorbtion spectroscopy (FAAS) (atomic absorbtion spectroscopy, AAS) method in the extract of calcium chloride;

7. determination of exchangeable cations $(\mathrm{Ca}, \mathrm{Mg}, \mathrm{K}, \mathrm{Na})$ with an FAAS method;

8. determination of organic carbon (oxidisable), total organic carbon (TOC) with a titration method according to Tiurin;

9. determination of $\mathrm{Cl}^{-}$with a ionomer method in the extract of $0.03 \mathrm{~N}$ acetic acid;

10. determination of $\mathrm{S}-\mathrm{SO}_{4}$ with a nephelometric method;

11. determination of Nog with a distillation-titration method (Kieltec Auto 8200);

12. determination of total forms of heavy metals, $\mathrm{Cu}, \mathrm{Cd}, \mathrm{Pb}$, $\mathrm{Zn}, \mathrm{Mn}$, with an atomic absorbtion spectroscopy, AAS method after mineralisation in aqua regia;

13. determination of total forms of soil macroelements, $\mathrm{Na}$, $\mathrm{Ca}, \mathrm{Mg}, \mathrm{K}$, with an atomic absorbtion spectroscopy, AAS method after mineralisation in aqua regia;

14. determination of $\mathrm{CaCO}_{3}$ with Scheilbler's method;

15. determination of $\mathrm{Hx}$ and Alx with Sokolov's method;

16. determination of size composition with Casagrande's aerometric method modified by Prószyński.

\section{RESULTS AND DISCUSSION}

As far as urban vegetation is concerned, trees growing in the surrounding of streets are the most vulnerable to a negative impact of urban environment [Borowski, Latocha 2006]. The content of heavy metals and plant-available nutrients as well as reaction and soil salinity are significant [Cekstere, Osvalde 2013]. Pant-availability is a measure of the ability of soil to supply plants with nutrients according to their needs. Knowledge about the content of plant-available nutrients in soils allows for a proper assessment of the supply with macroelements.

Table 1 shows the content of macroelements and exchangeable cations in the analysed soils.

Grain-size composition is one of the main characteristics of soils that determines the sorption qualities and mobility of heavy metals. The content of dust and clay fractions have a key role in shaping soil properties [Rejman et al. 2011]. All the analysed soils were characterised by the dominant percentage share of sand fraction (ranging from $54 \%$ to $81 \%$ ) as well as high content of clay fraction oscillating at the level of $22-25 \%$. The soils collected in the habitat of necrotic elm from the depth of 0-0.2 m were the exceptions, as they were characterised by the very low percentage share of that fraction at the level of $7 \%$. Significant differences in grain-size composition of the surface soil layers may result from anthropogenic additions.

The grain-size groups and subgroups of the analysed groups were determined on the basis of the classification of the Polish Science of Soil Society [2009]. The soils in the habitat of necrotic elm are light (loamy sand) at the surface soil layers and heavy 
Table 1. The content of macroelements and exchangeable cations in the soils from the habitats of the necrotic and alive elms

\begin{tabular}{|c|c|c|c|c|c|}
\hline \multirow{2}{*}{ Parameter } & \multirow{2}{*}{ Unit } & \multicolumn{2}{|c|}{ Necrotic elm } & \multicolumn{2}{|c|}{ Alive elm } \\
\hline & & $0-0.2 \mathrm{~m}$ & $0.5-0.7 \mathrm{~m}$ & $0-0.2 \mathrm{~m}$ & $0.5-0.7 \mathrm{~m}$ \\
\hline $\mathrm{P}_{2} \mathrm{O}_{5}$ & \multirow{3}{*}{$\begin{array}{c}\mathrm{mg} / 100 \mathrm{~g} \\
\text { Plant-available forms }\end{array}$} & 21.0 & 1.4 & 18.5 & 1.9 \\
\hline $\mathrm{K}_{2} \mathrm{O}$ & & 18.0 & 16.8 & 12.3 & 10.2 \\
\hline Mg & & 6.6 & 5.5 & 0.850 & 0.088 \\
\hline $\mathrm{S}-\mathrm{SO}_{4}$ & $\mathrm{mg} / 100 \mathrm{~g}$ & 0.850 & 0.088 & 0.023 & 0.012 \\
\hline $\mathrm{Na}$ & \multirow{4}{*}{$\begin{array}{l}\mathrm{g} / \mathrm{kg} \\
\text { total forms }\end{array}$} & 0.082 & 0.490 & 0.068 & 0.099 \\
\hline $\mathrm{Ca}$ & & 3.90 & 0.571 & 3.69 & 0.61 \\
\hline Mg & & 0.504 & 0.876 & 0.791 & 0.760 \\
\hline K & & 0.472 & 1.010 & 0.540 & 0.402 \\
\hline $\mathrm{Cl}^{-}$ & $\mathrm{mg} / \mathrm{kg}$ & 0.45 & 0.35 & 0.35 & 0.10 \\
\hline $\mathrm{Ca}^{2+}$ & \multirow{4}{*}{$\begin{array}{c}\text { Exchangeable } \\
\text { cations } \\
\mathrm{cmol}(+) / \mathrm{kg}\end{array}$} & 8.48 & 3.38 & 10.93 & 2.45 \\
\hline $\mathbf{K}^{+}$ & & 0.42 & 0.37 & 0.28 & 0.15 \\
\hline $\mathrm{Na}^{+}$ & & 0.08 & 1.54 & 0.06 & 0.04 \\
\hline $\mathbf{M g}^{2+}$ & & 0.51 & 0.36 & 0.58 & 0.44 \\
\hline$S$ (CEC) & $\mathrm{cmol}(+) / \mathrm{kg}$ & 9.49 & 5.65 & 11.85 & 3.08 \\
\hline
\end{tabular}
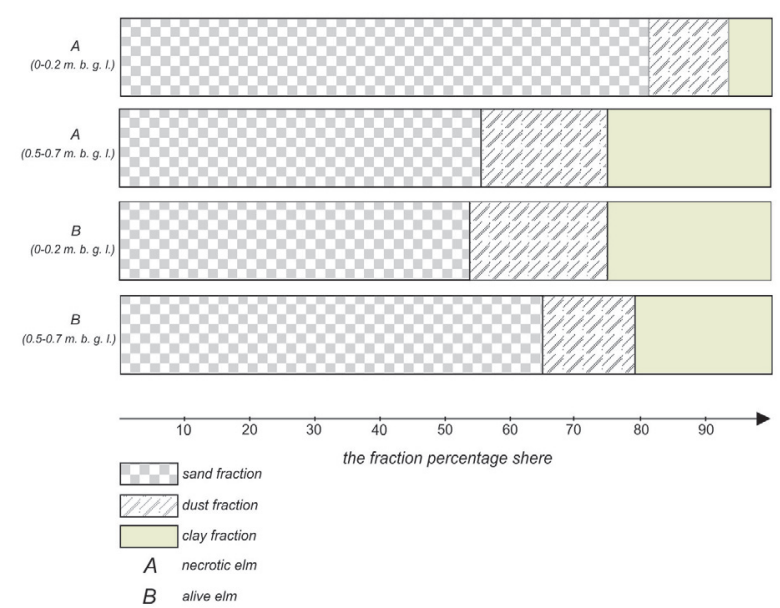

Fig. 1. Differentiation of grain-size composition of the analysed soils

(sandy clay loam) at the further soil layers. The soils in the habitat of alive elm are heavy - sandy clay loams.

Phosphorus is one of these elements that has a key role in the metabolism of plants. Its deficiency, especially in early stages of development, results in a weakening of root system growth, which translates into water-retrieving abilities. Only a small amount of phosphorus exists in soils as plant-available forms. It is assumed that these values amount to several tens of milligram per $100 \mathrm{~g}$ of soil [Terelak et al. 1995]. The analysed soil samples had comparable values for soils from the surroundings of the necrotic and alive trees. The surface layers of the soil from the habitat of the necrotic tree included more $\mathrm{P}_{2} \mathrm{O}_{5}$ - this soil was also characterised by greater variability of the content in the soil profile.

Significant differentiations in values were noted for potassium and magnesium. The soil from the habitat of the necrotic elm was richer in plant-available forms of these macroelements. No significant change in the content of potassium and magnesium alongside with the change in the depth of the soil profile was observed. Participation of potassium is connected with soil mineral component, thus organic soils and the ones rich in organic carbon are usually poor in potassium [Burzyńska 2012]. The above is evidenced by the results of the conducted studies. The total content of potassium in the Polish soils varies within wide limits and is generally higher than the content of phosphorus. The studies conducted on the soils in the City of Opole indicated higher values of $\mathrm{K}^{+}$than those of the present studies [Kochanowska, Kusza 2010].

The content of plant-available magnesium in the surface layers of the soils in Poland ranges from 0.1 to $33.6 \mathrm{mg} \mathrm{Mg} / 100 \mathrm{~g}$. The content of this macroelement in the analysed soils should be regarded as average (the range for clay soils amounts to $5.1-7.0 \mathrm{mg} \mathrm{Mg} / 100 \mathrm{~g}$ ) and high (the range amounts to $7.1-9.0 \mathrm{mg} \mathrm{Mg} / 100 \mathrm{~g}$ ) [Terelak et al. 1995]. The soil samples collected from the surrounding of the necrotic elm were characterised by the content of magnesium, which was several times higher than those collected from the surrounding of the alive elm. The content of magnesium increases along with the participation of organic matter.

In order to assess the state of the content of sulphur in soils, supply of plants with this element and risk of its excess for agroecosystems, total and sulphate forms of it are usually taken into account. Motowicka-Terelak and Terelak [2000] reported that the content of sulphur in the soils of Poland ranged from 0.1 to $775 \mathrm{mg} \mathrm{S}-\mathrm{SO}_{4} / \mathrm{kg}$ of soil and adopted $17.9 \mathrm{mg} \mathrm{S}-\mathrm{SO}_{4} / \mathrm{kg}$ of soil on an average. Trelak et al. [1995] indicated that the smaller content of $\mathrm{S}_{-} \mathrm{SO}_{4}$ in the surface layers of soils developed from sands ( $15 \mathrm{mg} \mathrm{S}-\mathrm{SO}_{4} / \mathrm{kg}$ of soil on an average) in comparison to those developed from heavy clays ( $20 \mathrm{mg} \mathrm{S}-\mathrm{SO}_{4} / \mathrm{kg}$ of soil). The content of $\mathrm{S}_{-} \mathrm{SO}_{4}$ in the analysed soils should be regarded as low and not exceed the average values for the soils in Poland. However, whilst making comparisons, the content of this element was several times higher in the soil samples collected from the surrounding of the necrotic elm than in those collected from the surrounding of the alive elm (Table 1). As noted by DuszaDobek [2012], enrichment of surface soil layers depends on the anthropogenic factors, which is evidenced by the fact that the content of element declines along with the soil profile depth.

Low content of plant-available biogenic elements may lead to physiological disorders in plants as reported by Dusza-Dobek 
[2012]. The conducted soil studies indicate that the content of plant-available forms of macroelements oscillates around an average level. Moreover, the content of plant-available macroelements was several times higher than that indicated by the studies conducted on the soils of urban parks in Warsaw [Dusza-Dobek 2012].

Studies conducted by a number of scientists confirm that $\mathrm{NaCl}$, used as de-icing salt, has a negative impact on plants by causing discoloration of leaves, decay and, consequently, necrosis [Brogowski et al. 2000, Gałuszka et al. 2010, Mazur et al. 2011]. Czerniakowska-Kusza et al. [2003] indicated that the degree of damage to plants directly relates to the content of sodium and chloride ions in soils, as well as depends on the seasons and remoteness from roads. Significant differences in the content of sodium were noted in the analysed soils. The soils in the surrounding of the elm at Prosta Street were characterised by the content of sodium at the level of $0.068-0.099 \mathrm{~g} / \mathrm{kg}$. These values were significantly higher in the case of the soils in the surrounding of the necrotic elm. Moreover, it was noted that the content of sodium was several times higher in the deeper layers of the soils from the habitat of the necrotic elm, which proves the migration of sodium into the soil profile and its higher availability for the tree roots. Sodium is an active soil migrant which easily infiltrates with rain water into deeper soil layers. It is also hardly absorbable by clay minerals. The presence of excessive amounts of sodium in soils destroy a lumpy structure, increases dispersion state, as well as decreases permeability and moisture absorption [Brogowski et al. 2000]. However, as noted in the studies by Kuznietsov et al. [1999], elm is a species relatively resistant to salinity.

The studies conducted in Riga [Cekstere, Osvalde 2013] indicate that trees are damaged when there is an unfavourable balance of nutrients. The most crucial is the $\mathrm{Na}: \mathrm{K}$ ratio, which should oscillate at the level of 2:2.5. The Na:K ratio in the studies conducted on the elms in Kielce deviates from the above dependencies, but in all variants, the value of potassium is higher than that of sodium, which eliminates disorders in absorption of nutrients by the trees [Cekstere et al. 2005].

The values for the total forms of calcium and magnesium in the analysed soils were found to be comparable. The dominant content of calcium was reported for the surface soil layers. The values were significantly differentiated in the case of potassium. Its highest content was noted for the samples collected from the depth of $0.5-0.7 \mathrm{~m}$ in the habitat of the necrotic elm. Oleksyn et al. [2007] indicated that soils surrounded by roads contain more potassium than sodium. The increased content of calcium and magnesium in the surface layers of the analysed soils was, in turn, caused by admixtures of construction waste or fertilisers. Similar dependencies were found in the studies by Bach et al. [2006] and Oleksyn et al. [2007].

The Ca:Na ratio regarded as favourable should amount to $\geq 10: 1$ [Cekstere, Osvalde 2013]. This dependency was not fulfilled in all analysed cases, which may have a negative impact on the absorption of calcium by plants.

The Mg:K ratio that is the most favourable amounts to $2: 1$. The dependency obtained for the soils in the habitat of the alive elm was close to optimum one, whilst that from the habitat of the necrotic elm was found in disturbance. A crucial factor is also the Ca:Mg ratio in soils (the optimal one according to Cekstere and Osvalde [2013] oscillates at the level of 5:8). This dependency was fulfilled in all analysed soil samples collected from the depth of $0.5-0.7 \mathrm{~m}$. In the case of the surface soil layers, the increased values were reported for calcium.

The increased accumulation of sodium at the depth below $60 \mathrm{~cm}$, with its natural content at the depth of $20 \mathrm{~cm}$, may indicate internal salinity, which remains due to the high content of clay fractions in the soil. The saline anthropogenic soils after cessation of a causative factor (e.g. $\mathrm{NaCl}, \mathrm{CaCl}_{2}$ ) undergo desalination quite rapidly. This concerns especially soils that are permeable. In order to classify soils as anthropologically saline, the presence of $>2 \%$ of soluble salts should be stated. An increased accumulation of $\mathrm{Na}^{+}$ion in a sorption complex is usually noted during autumns when rain falls intensify the migration of sodium into deeper soil layers.

Chlorine exists naturally in soils, usually in very small amounts, and its content is in the range of $115-1,000 \mathrm{mg} / \mathrm{kg}$. Chlorides are not absorbed by soil sorption complex and easily become a solution that facilitates their leaching from soils. A significant source of chlorides, especially in urban soils, is salt used to remove glazed frost. The studies show that sodium and chlorine are leached from the surface soil layers into deeper ones where they are absorbed by the roots.

As a result, an increased content of salt during winters may cause disorders in plant growth because of the fact that that the compounds of sodium and chlorine are much more rapidly absorbed by plants than those of sulphur and phosphorus [Cekstere, Osvalde 2013]. Chlorine is a macroelement essential for plant growth; however, high concentrations of ions and salts may have a negative impact on plants by causing the so-called osmotic shock and physiological drought [Czerniawska-Kusza et al. 2004, Sinclair, Lyon 2005]. An excess of $\mathrm{Na}^{+}$and $\mathrm{Cl}$ ions may result in disturbances in ionic economies of plants, caused by a limited absorption of ions such as $\mathrm{K}^{+}, \mathrm{Ca}^{2+}, \mathrm{Mg}^{2+}$ and $\mathrm{NO}^{3-}$ [Breś 2008].

Moderate and short-term salinity stress triggers defensive reactions of plants, but as a result of long-term impact of salts on susceptible plants, as observed, their growth is substantially inhibited and they even undergo necrosis [Bach et al. 2006, Breś 2008]. Urban soils that contain over $5 \mathrm{mg} \mathrm{Cl} / 100 \mathrm{~g}$ of soil are considered to be saline [Mazur et al. 2011]. The studies indicated that the content of chlorine ions, $\mathrm{Cl}^{-}$, in the analysed samples is in the range of $0.10-0.45 \mathrm{mg} / \mathrm{kg}$, which should be regarded as low values. The above statement is additionally confirmed by the studies conducted on the soils in the City of Olsztyn [Mazur et al. 2011], where significantly higher values of chlorides were noted. Table 2 shows the results of analyses of physicochemical properties of the analysed soils along with the values of total forms of selected heavy metals.

Alkalisation ( $\mathrm{pH}$ of up to 8.44 in $\mathrm{KCl}$ and 9.69 in $\mathrm{H}_{2} \mathrm{O}$ ), high content of calcium (up to $650 \mathrm{mg} / 100 \mathrm{~g}$ ), strong salinity (more than $20 \mathrm{mg} \mathrm{Na} / 100 \mathrm{~g}$ ), high degree of saturation of sorption complex with sodium ions (exceeding $20 \%$ ) as well as increased content of copper, lead and zinc, indicating soil contamination are quite frequently mentioned amongst the causes of tree necrosis [Cekstere, Osvalde 2013]. 
Table 2. Physicochemical properties of the analysed soils, including the content of total forms of selected heavy metals

\begin{tabular}{|c|c|c|c|c|c|}
\hline \multirow{2}{*}{ Parameter } & \multirow{2}{*}{ Unit } & \multicolumn{2}{|c|}{ Necrotic elm } & \multicolumn{2}{|c|}{ Alive elm } \\
\hline & & $0-0.2 \mathrm{~m}$ & $0.5-0.7 \mathrm{~m}$ & $0-0.2 \mathrm{~m}$ & $0.5-0.7 \mathrm{~m}$ \\
\hline $\mathrm{pH} \mathrm{H} \mathrm{H}_{2} \mathrm{O}$ & - & 7.33 & 5.65 & 7.28 & 5.66 \\
\hline $\mathrm{pH} \mathrm{KCl}$ & - & 6.95 & 5.45 & 7.11 & 6.01 \\
\hline PEC & $\mathrm{mS} / \mathrm{cm}$ & 1.08 & 0.95 & 0.24 & 0.10 \\
\hline $\mathrm{Hh}$ & \multirow{3}{*}{$\mathrm{cmol}(+) / \mathrm{kg}$} & 0.57 & 1.12 & 0.42 & 1.14 \\
\hline Alx & & 0.00 & 0.22 & 0.00 & 0.12 \\
\hline$H x$ & & 0.15 & 0.30 & 0.00 & 0.40 \\
\hline TOC & $\%$ & 2.02 & 0.42 & 3.52 & 0.04 \\
\hline Nog & $\mathrm{g} / \mathrm{kg}$ & 0.91 & 0.19 & 0.90 & 0.11 \\
\hline $\mathrm{CaCO}_{3}$ & $\%$ & 0.13 & 0.00 & 0.57 & 0.00 \\
\hline $\mathrm{Cu}$ & \multirow{5}{*}{$\begin{array}{c}\mathrm{mg} / \mathrm{kg} \\
\text { Total forms }\end{array}$} & 6.99 & 4.66 & 7.41 & 5.11 \\
\hline Cd & & 0.36 & 0.12 & 0.27 & 0.12 \\
\hline $\mathrm{Pb}$ & & 28.80 & 7.44 & 29.40 & 19.20 \\
\hline $\mathrm{Zn}$ & & 63.50 & 17.80 & 78.60 & 22.10 \\
\hline Mn & & 226.0 & 69.00 & 199.00 & 88.00 \\
\hline
\end{tabular}

One of the primary factors determining the plant growth is $\mathrm{pH}$ of soils. The optimum for majority of plants ranges from 5.5 to 7.8 . The high $\mathrm{pH}$ of soils is frequently related to salinity or contamination with alkaline waste and causes disorders in absorption of nutrients by trees [Borowski, Latocha 2006]. The present studies identify the range of soil $\mathrm{pH}$ from slightly acidic to slightly alkaline, what is typical for urban soils.

Measurement of PEC is one of the most frequently used parameters in order to study soil salinity. Toxic concentration occurs when PEC is more than $2 \mathrm{mS} / \mathrm{cm}$ [Dajic 2006]. Baran and Turski [1996], in turn, reported that the value of PEC is highly toxic and causes plant necrosis when it is more than $16 \mathrm{mS} / \mathrm{cm}$. The proper conductivity of water extracts from the analysed soils is much lower than the above values and ranges from 0.95 to $1.08 \mathrm{mS} / \mathrm{cm}$.

The acidity of the soils expressed by the content of hydrogen and exchangeable aluminium ions is low, as like hydrolytic acidity amounting from 0.57 to $1.12 \mathrm{cmol}(+) / \mathrm{kg}$, which is associated with the content of carbonates (up to $0.13 \%$ ) typical for the urban soils in Kielce.

The content of organic matter in the surface soil layer ranges from $2.02 \%$ to $3.52 \%$. The content of nitrogen generally ranges from 0.19 to $0.91 \mathrm{~g} / \mathrm{kg}$ (from $0.02 \%$ to $0.1 \%$ ). These values are typical for black agricultural soils.

Lead, zinc and cadmium have the highest bioaccumulation capacity amongst all heavy metals. The risk of inclusion of these heavy metals into the food chain occurs only if their content in soils is higher than $300 \mathrm{mg} / \mathrm{kg}$ d.m. for zinc, $100 \mathrm{mg} / \mathrm{kg} \mathrm{d.m}$. for lead and $3 \mathrm{mg} / \mathrm{kg}$ d.m. for cadmium [Dusza-Dobrek 2012]. The content of heavy metals in the soils of the Świętokrzyskie Province according to the monitoring research points in the years 2007-2013 was as follows: $\mathrm{Cu}(2.7-39.1 \mathrm{mg} / \mathrm{kg}), \mathrm{Cd}$ (0.2-1.6), $\mathrm{Pb}(7.4-101.9$ and $900-1438 \mathrm{mg} / \mathrm{kg}$ of the soil from the Karczówka Hill in Kielce, where galena ores exist naturally), $\mathrm{Zn}(2.5-223$ and $400-600 \mathrm{mg} / \mathrm{kg}$ of the soil from the vicinity of the Barcza Village) and Mn (up to $800 \mathrm{mg} / \mathrm{kg}$ ). The content of heavy metals such as $\mathrm{Cu}, \mathrm{Cd}, \mathrm{Pb}, \mathrm{Zn}$ and $\mathrm{Mn}$ in the analysed soil samples should be regarded as low and natural. The content of all these heavy metals is considerably lower than the limit values specified in the Ordinance of the Minister of Environment [2002]. The increased content of selected heavy metals in the vicinity of transportation routes in Kielce was indicated in a separate article [Świercz, Smorzewska 2015].

\section{CONCLUSIONS}

The analysed soils were characterised by natural content of heavy metals, low concentrations of chlorides and sulphates, as well as high and medium content of plant-available forms. These characteristics provide a good supply for plants with macroelements, and the values of $\mathrm{pH}$ in $\mathrm{H}_{2} \mathrm{O}$ ranging from 5.65 to 7.33 are typical for urban soils.

The soil samples collected from the depth of $0-0.2 \mathrm{~m}$ around the necrotic elm at Batalionów Chłopskich Street do not indicate unfavourable processes caused by the anthropogenic factors. The content that was identified for both macro- and microelements should be regarded as natural for this type of soils (leached black soils).

The increased content of sodium, both in its total form and the one included in the sorption complex, that is, $1.54 \mathrm{cmol}(+) / \mathrm{kg}$ in the soil sample collected from the depth of $0.5-0.7 \mathrm{~m}$, may be of natural as well as anthropogenic character. Concentration of sodium at this depth, especially in the soil sorption complex with a large proportion of clay fractions (medium silt loam), might have been a result of leaching from the surface soil layers with high salinity in the past and had a negative impact on water transportation in plants. In the case of the analysed soil samples, the present salinity was not excessively high and amounted to $0.95-1.08 \mathrm{mS} /$ $\mathrm{cm}$. The increased content of sodium in the sorption complex, low content of plant-available forms of phosphorus in soils and, for example, weakening of the tree because of quite common fungal disease caused by Ophiostoma ulmi could also have 
had an impact on acceleration of necrotic processes of the tree. At present, it cannot be, however, determined whether and to what extent the tree has been overtaken by Dutch elm disease and if this is the only factor causing its necrosis.

\section{REFERENCES AND LEGAL ACTS}

BACH A., PAWŁOWSKA B., KRAUSE D., MALINOWSKA Z., PNIAK M., BARTYŃSKA M. 2006. Reakcja roślinności drzewiastej pasów przydrożnych Krakowa na zasolenie i pH gleby. Zesz. Probl. Post. Nauk Rol., 510: 39-48.

BACZEWSKA A.H., DMUCHOWSKI D., JÓŹWIAK A., GOZDOWSKI D., BRĄGOSZEWSKA P., DĄBROWSKI P. SWIEZEWSKA E. 2014. Effect of Salt Stress on Prenol Lipids in the Leaves of Tilia 'Euchlora'. Dendrobiology, 72: 177-186.

BARAN S., TURSKI S. 1996. Degradacja. ochrona i rekultywacja gleb. Wydawnictwo Akademii Rolniczej w Lublinie, Lublin.

BREŚ W. 2008. Czynniki antropopresji powodujące zamieranie drzew w krajobrazie miejskim. Nauka Przyroda Technologie, 2(4): 1-8.

BURZYŃSKA I. 2012. Potas w glebie, roślinności i płytkich wodach gruntowych na tle zróżnicowanego użytkowania. Woda Środowisko-Obszary Wiejskie, 12(1): 49-58.

BOROWSKI J., LATOCHA P. 2006. Dobór drzew i krzewów do warunków przyulicznych Warszawy i miast centralnej Polski. Rocznik Dendrologiczny, 54: 83-93.

BROGOWSKI Z., CZARNOWSKA K., CHOJNICKI J., PRACZ J., ZAGÓRSKI Z. 2000. Wpływ stresu solnego na stan chemiczny liści drzew z terenu miasta Łodzi. Rocz. Glebozn., 51 (1/2): 17-28.

CEKSTERE G., OSVALDE A., KARLSONS A., NOLLENDORFS V., PAEGLE G. 2005. The effect of urban environment on the mineral nutrition status of street trees in Riga. The problems and possible solution. Acta Universitatis Latviensis. Earth \& Environment Sciences, 685: 7-20.

CEKSTERE G., OSVALDE A. 2013. A Study of Chemical Characteristics of Soil in Relation to Street Trees Status in Riga (Latvia). Urban Forestry \& Urban Greening, 12:69- 78.

CHUDECKA J. 2013. Zawartość Zn, Cu, Pb oraz zasolenie gleb terenów zieleni zlokalizowanych w centrum Szczecina. Agric. Aliment. Pisc. Zootech., 304(26) 5-12.

CUNNINGHAM M.A., SNYDER E., YONKIN D., ROSS M., ELSEN T. 2008. Accumulation of Deicing Salts in Soils in an Urban Environment. Urban Ecosyst., 11: 17-31.

CZERNIAWSKA-KUSZA I., KUSZA G., DUŻYŃSKI M. 2003. Effect of Deicing Salts on Urban Soils and Health Status of Roadside Trees in the Opole Region Periodicals. Inc. Environ Toxicol., 19: 296-301.

CZERNIAWSKA-KUSZA I., KUSZA G., DUŻYŃSKI M. 2004. Effect of Deicing Salts on Urban Soils and Health Status of Roadside Trees in the Opole Region. Environtal Toxicology, 19: 296-301.

DAJIC Z. 2006. Salt Stress. In: Physiology and Molecular Biology of Stress Tolerance in Plants. (eds.). Madhava Rao K.V., Raghavendra A.S., Janardhan Reddy K., Springer, Dordrecht, pp. 41-99.
DMUCHOWSKI W., BADUREK M. 2004. Chloride and Sodium in the Leaves of Urban Trees in Warsaw in Connection to Their Health Condition. Ecological Chemistry and Engineering, 11: 297-303.

DUSZA-DOBEK A. 2012. Badania geochemiczne gleb w wybranych parkach Warszawy. Biuletyn Państwowego Instytutu Geologicznego, 450: 35-46.

HARTL W., ERHART E. 2002. Effects of Potassium Carbonate as an Alternative Road Deicer to Sodium Chloride on Soil Chemical Properties. Annals of Applied Biology, 140: 271-277.

GAŁUSZKA A., MIGASZEWSKI Z.M., Podlaski R., Dołęgowska S., Michalik A. 2010. The Influence of Chloride Deicers on Mineral Nutrition and the Health Status of Roadside Trees in the City of Kielce, Poland. Environmental Monitoring and Assessment, 176(1-4): 451-464.

KOCHANOWSKA K., KUSZA G. 2010. Wpływ zasolenia na właściwości fizyko-chemiczne gleb Opola w latach 1994 i 2009. Inżynieria Ekologiczna, 23: 14-21.

KUZNETSOV V.V., SHEVYAKOVA N.I., KARPACHEVSKIYL O. 1999. New Approaches to Greek Plantations in Megapolises. Problems to control Over the Environment Quality, pp. 223.

MARCINEK J., KOMISAREK J. 2011. Systematyka gleb Polski, Wydanie 5, 2011.

MAZUR Z., RADZIEMSKA M., DEPTUŁA D. 2011. Wpływ środków zwalczania śliskości jezdni na zawartość chlorków w glebach wzdłuż ulic Olsztyna. Ochrona Środowiska i Zasobów Naturalnych, 50: 212-217.

MOTOWICKA-TERELAK T., TERELAK H. 2000. Siarka w glebach i roślinach Polski. Zesz. Nauk AR w Szczecinie, Rolnictwo, 81: 7-16.

OLEKSYN. J., KLOEPPEL B.D., LUKASIEWICZ S., KAROLEWSKI P., REICH P.B. 2007. Ecophysiology of Horse Chestnut (Aesculus hippocastanum L.) in Degraded and Restored Urban sites. Polish Journal of Ecology, 55: 245-260. POLISH SOCIETY OF SOIL SCIENCE. 2009. Classification of Grain-Size Composition of Soils and Mineral Formations PSSS 2008. Soil Science Annual 60(2): 5-16.

REJMAN J., IGLIK I., BRODOWSKI R., TURSKI M., SMARZ M. 2001. Evaluation of Spatial Variability of Soil Texture and Organic Content in Soil in a Loess Landscape. Acta Agrophysica, 18(2): 409-419.

Rozporządzenie Ministra Środowiska z dnia 9 września 2002 r. w sprawie standardów jakości gleby oraz standardów jakości ziemi (Dz.U. 2002 nr 165 poz. 1359.).

SZCZEPANOWSKA H.B. 2001. Drzewa w mieście. Hortpress. Warszawa.

SINCLAIR W.A., LYON H.H. 2005. Diseases of Trees and Shrubs: Second Edition, Comstock Publishing Associates. Cornell University Press. Ithaca, NY. 
ŚWIERCZ A., SMORZEWSKA E. 2015. Variations in the Zinc and Lead Content in Surface Layers of Urban Soils in Kielce (Poland) with Regard to Land Use. J. Elem., 20 (2): 449-461. TERELAK H., PIOTROWSKA M., MOTOWICKA-TERELAK T., STUCZYŃSKI T., BUDZYŃSKA K. 1995. Zawartość metali ciężkich i siarki w glebach użytków rolnych Polski oraz ich zanieczyszczenie tym składnikiem. Zesz. Probl. Post. Nauk Rol. 418: 45-59. 